University of Nebraska - Lincoln

DigitalCommons@University of Nebraska - Lincoln

2006

\title{
Ecophysiology of Two Native Invasive Woody Species and Two Dominant Warm-Season Grasses in the Semiarid Grasslands of the Nebraska Sandhills
}

\author{
Kathleen D. Eggemeyer \\ University of Nebraska-Lincoln \\ Tala Awada \\ University of Nebraska - Lincoln, tawada2@unl.edu \\ David A. Wedin \\ University of Nebraska-Lincoln, dwedin1@unl.edu \\ F. Edwin Harvey \\ University of Nebraska - Lincoln, feharvey1@unl.edu \\ Xinhua Zhou \\ University of Nebraska - Lincoln, xzhou2@unl.edu
}

Follow this and additional works at: https://digitalcommons.unl.edu/natrespapers

Part of the Natural Resources and Conservation Commons

Eggemeyer, Kathleen D.; Awada, Tala; Wedin, David A.; Harvey, F. Edwin; and Zhou, Xinhua, "Ecophysiology of Two Native Invasive Woody Species and Two Dominant Warm-Season Grasses in the Semiarid Grasslands of the Nebraska Sandhills" (2006). Papers in Natural Resources. 269.

https://digitalcommons.unl.edu/natrespapers/269

This Article is brought to you for free and open access by the Natural Resources, School of at DigitalCommons@University of Nebraska - Lincoln. It has been accepted for inclusion in Papers in Natural Resources by an authorized administrator of DigitalCommons@University of Nebraska - Lincoln. 
Int. J. Plant Sci. 167(5):991-999. 2006.

(c) 2006 by The University of Chicago. All rights reserved.

$1058-5893 / 2006 / 16705-0008 \$ 15.00$

\title{
ECOPHYSIOLOGY OF TWO NATIVE INVASIVE WOODY SPECIES AND TWO DOMINANT WARM-SEASON GRASSES IN THE SEMIARID GRASSLANDS OF THE NEBRASKA SANDHILLS
}

\author{
Kathleen D. Eggemeyer, Tala Awada, ${ }^{1}$ David A. Wedin, F. Edwin Harvey, and Xinhua Zhou \\ School of Natural Resources, University of Nebraska, Lincoln, Nebraska 68583, U.S.A.
}

\begin{abstract}
Populations of Pinus ponderosa and Juniperus virginiana are expanding into semiarid Sandhills grasslands in Nebraska. To evaluate the physiological basis of their success, we measured the seasonal course of leaf gas exchange, plant water status, and carbon isotope discrimination in these two native trees and two native $\mathrm{C}_{4}$ grasses (Schizachyrium scoparium and Panicum virgatum). Compared to the trees, grasses had higher net photosynthetic rates $\left(A_{\text {net }}\right)$ and water use efficiency (WUE) and more negative predawn and midday water potentials $(\Psi)$ in June and July. While leaf $\Psi$ and rates of leaf gas exchange declined for all four species during August, the $\Psi_{\text {mid }}$ of the grasses were significantly more negative than those of the two trees. The deeply rooted trees maintained water status during summer, in contrast to the grasses, which senesced. Juniperus virginiana in particular was well adapted to xeric conditions, with low stomatal conductance, high WUE, and positive $A_{\text {net }}$ at low $\Psi$. The highest values of $A_{\text {net }}$ were observed in May for J. virginiana and in May and September for $P$. ponderosa. Both species maintained low but positive $A_{\text {net }}$ throughout the winter at temperatures above $0^{\circ} \mathrm{C}$. Leaf carbon isotopic signature differed between tree and grass species but did not exhibit significant withinspecies seasonal variability. The semiarid grassland climate of Nebraska does not appear to limit $P$. ponderosa and J. virginiana, which use growth during the nongrowing season and access to deep soil moisture to compensate for growing-season drought.
\end{abstract}

Keywords: Schizachyrium scoparium, Panicum virgatum, Pinus ponderosa, Juniperus virginiana, water relations, photosynthesis, carbon isotope discrimination.

\section{Introduction}

Temperature and precipitation have long been viewed as key factors determining vegetation type, including transitions between grassland, savanna, and forest (Bond et al. 2005). In recent decades, however, a shift in vegetation cover from grasslands and savannas to open-canopy forests and, in some instances, closed-canopy forests has been reported in semiarid ecosystems worldwide (Bragg and Hulbert 1976; Steinauer and Bragg 1987; Archer 1995; Brown and Carter 1998; Dussart et al. 1998; Moleele and Perkins 1998; Jackson et al. 2002; Bond et al. 2005; Ebert 2005; Huxman et al. 2005). This expansion, or invasion, of woody species into grasslands and savannas has been attributed to changes in land management and anthropogenic disturbances over the past century (McCarron and Knapp 2001). Fire frequency has decreased in grasslands and savannas worldwide, litter has accumulated, grass production has declined, and woody vegetation has increased (Gibson and Hulbert 1987; McCarron and Knapp 2001; Bond et al. 2005).

In the Great Plains of North America, such vegetation shifts are well documented. For example, eastern redcedar (Juniper virginiana L.) has expanded into the tallgrass prairie in Kansas and Oklahoma and the Sandhills of Nebraska

\footnotetext{
${ }^{1}$ Corresponding author; telephone 402-472-8483; fax 402-4722946; e-mail tawada@unl.edu.
}

Manuscript received January 2006; revised manuscript received May 2006.
(Bragg and Hulbert 1976; Engle et al. 1996; Hoch 2000; Briggs et al. 2002). Mesquite (Prosopis glandulosa Torr.) has been replacing grasslands in west Texas (Archer 1995). Ponderosa pine (Pinus ponderosa P.\&C. Lawson) has expanded into grasslands in the Black Hills of South Dakota (Shinneman and Baker 1997) and the Pine Ridge and Niobrara Valley of Nebraska (Steinauer and Bragg 1987). Unlike ponderosa pine, which is expanding from historical grassland-woodland ecotones, eastern redcedar in Nebraska is spreading throughout the Sandhills (Briggs et al. 2002), invading more than 20,000 ha of grasslands in the past $10 \mathrm{yr}$ (USDA Forest Service, personal communication) and resulting in complete conversion to closed-canopy forests in as little as $40 \mathrm{yr}$ (Hoch 2000).

Available soil moisture is a key determinant of vegetation structure and distribution in water-limited grasslands (Kolb and Robberecht 1996a). Success in these ecosystems depends on species' ability to access water, which in turn is determined by environmental conditions, root distribution, and root competition (Schenk and Jackson 2002). Trees and grasses use overlapping areas in the soil profile. However, grasses are viewed as being superior competitors for water in the upper soil profile, whereas trees are known to have access to deeper water due to their extensive rooting systems (Belsky 1994). The coexistence of trees and grasses in open savannas and grasslands was initially attributed to their ability to vertically stratify soil water (Walter 1979). Studies have since shown that trees and grasses compete for available 
soil water throughout the overlapping soil profiles (Le Roux et al. 1995; Scholes and Archer 1997; Eggemeyer 2005). Physiologically, the warm-season $\mathrm{C}_{4}$ grasses that dominate the Great Plains are distinguished from $\mathrm{C}_{3}$ trees by having lower $\mathrm{CO}_{2}$ compensation points, higher light saturation points, higher photosynthetic rates, and higher water and nitrogen use efficiencies, potentially making them better suited for semiarid environments (Jones 1992; Wedin 2004). This is consistent with the traditional view that a "grassland" climate, together with competition from grasses, precludes the success of trees in native grasslands of the Great Plains (Weaver and Clements 1938; Weaver 1965). However, skeptics have long questioned this view. Wells (1965, pp. 246247) concluded, "It is, therefore, misleading to describe the range of climate in the Great Plains as a grassland or steppe climate, with the implication that precipitation, or a combination of precipitation and potential evapotranspiration, is limiting for tree growth.... Apparently, there is no range of climate in the vast grassland province of the central plains of North America which can be described as too arid for all species of trees native to the region."

Differences in physiology, phenology, and rooting patterns between trees and grasses affect their responses to environmental stresses and may contribute to the success of trees in semiarid grasslands and savannas. The objectives of this study were to determine whether differences in ecophysiological characteristics and responses to environmental stresses in two native woody species ( $P$. ponderosa and J. virginiana) and two native dominant $\mathrm{C}_{4}$ grasses (Schizachyrium scoparium [Michx.] Nash and Panicum virgatum L.) explain the success of woody species in the semiarid Sandhills grasslands of Nebraska.

\section{Material and Methods}

\section{Site Description}

The study was conducted at the Nebraska National Forest (NNF), Halsey, Nebraska (825 m altitude, lat. $41^{\circ} 51^{\prime} 45^{\prime \prime} \mathrm{N}$, long. $\left.100^{\circ} 22^{\prime} 06^{\prime \prime} \mathrm{W}\right)$. The NNF is an experimental forest established in the semiarid Sandhills grasslands of Nebraska in 1902 and was hand-planted with coniferous species, mainly Pinus ponderosa. The documented site history and the relatively uniform age of plantations and soils at the NNF make it uniquely suited to address the issue of tree expansion in the Great Plains.

The climate on site is semiarid continental. Average annual precipitation is $570 \mathrm{~mm}$, with $75 \%$ falling during the growing season (April-September). The average annual temperature is $8.6^{\circ} \mathrm{C}$. The average low temperature in January is $-13^{\circ} \mathrm{C}$, and the average high temperature in July is $31^{\circ} \mathrm{C}$. Soils are loose, well-drained Valentine fine sand (mixed, mesic Typic Ustipsamments; Sherfey et al. 1965). The study site was an open savanna (basal area $=5.6 \mathrm{~m}^{2} \mathrm{ha}^{-1}$ ) composed of an overstory of ponderosa pine ( $P$. ponderosa) and eastern redcedar (Juniperus virginiana) and a perennial grassland understory community of prairie sandreed (Calamovilfa longifolia [Hook.] Scribn.), Kentucky bluegrass (Poa pratensis L.), little bluestem (Schizachyrium scoparium), switchgrass (Panicum virgatum), yucca (Yucca spp. L.), and prickly pear (Opuntia spp. P. Mill). Four native species were selected for this study: two woody species ( J. virginiana and $P$. ponderosa) and two dominant $\mathrm{C}_{4}$ grass species ( $S$. scoparium and P. virgatum). Ponderosa pine trees used in the study averaged $0.44 \mathrm{~m}$ dbh (range $0.35-0.52 \mathrm{~m}$ ), and eastern redcedars averaged $0.18 \mathrm{~m} \mathrm{dbh}$ (range $0.11-0.24 \mathrm{~m}$ ). The grasses were well-established, large clumps that were located in the open at least $10 \mathrm{~m}$ outside the canopy shade. Schizachyrium scoparium and $P$. virgatum have fibrous root systems that can extend up to 0.6 and $1.2 \mathrm{~m}$ deep, respectively (Stubbendieck et al. 1985). In comparison, the roots of J. virginiana and P. ponderosa can penetrate up to 7.5 and $12 \mathrm{~m}$ deep, respectively (Burns and Honkala 1990).

\section{Microclimate}

A weather station with temperature and relative humidity probes (CS500; Campbell Scientific, Logan, UT), a quantum sensor (LI-190-SA; LICOR, Lincoln, NE), and a tippingbucket rain gauge (TE525; Texas Electronics, Dallas, TX) was installed on site. Two replicate sets of soil moisture sensors were also installed at soil depths of $0.15,0.4,0.6$, and $1 \mathrm{~m}$ (time domain reflectometry technology; ML2 Thetaprobes, Dynamax, Houston). Data were collected every $10 \mathrm{~s}$, averaged over $30 \mathrm{~min}$, and stored on a data logger (CR10X; Campbell Scientific).

\section{Gas Exchange}

Seasonal and diurnal courses in gas exchange were followed once a month on five individuals per species over a 1-yr period (July 1, 2003-June 30, 2004) for the trees and over the growing season (June-August) for the grasses. Plants were tagged, and the same individuals were measured on

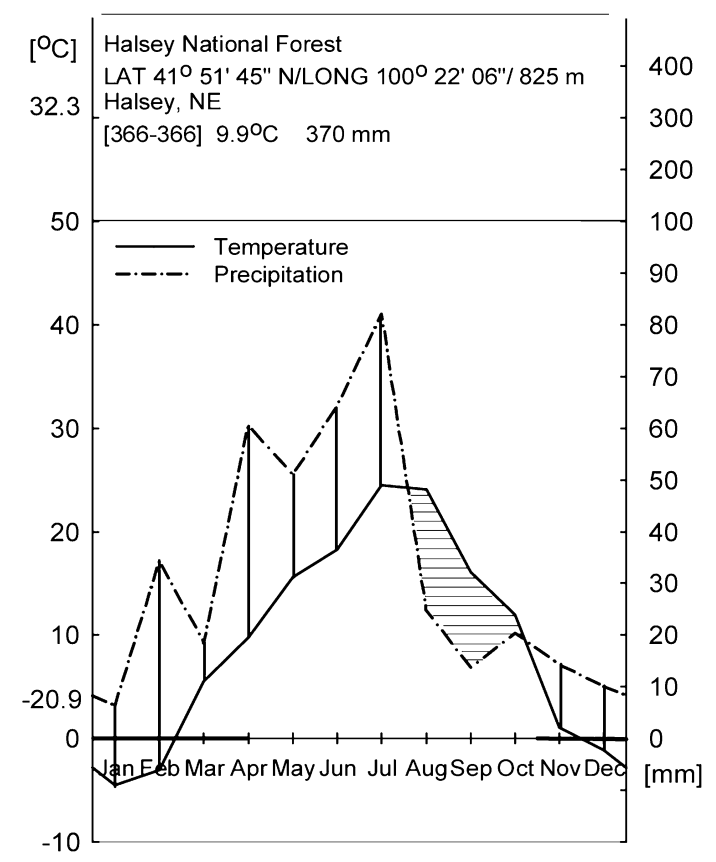

Fig. 1 Climate diagram of mean monthly temperature and precipitation data for the Nebraska National Forest, Halsey, during the study period. Horizontal and vertical lines indicate relative drought and humid periods, respectively. Bold dates (on $X$-axis) indicate frost periods. 


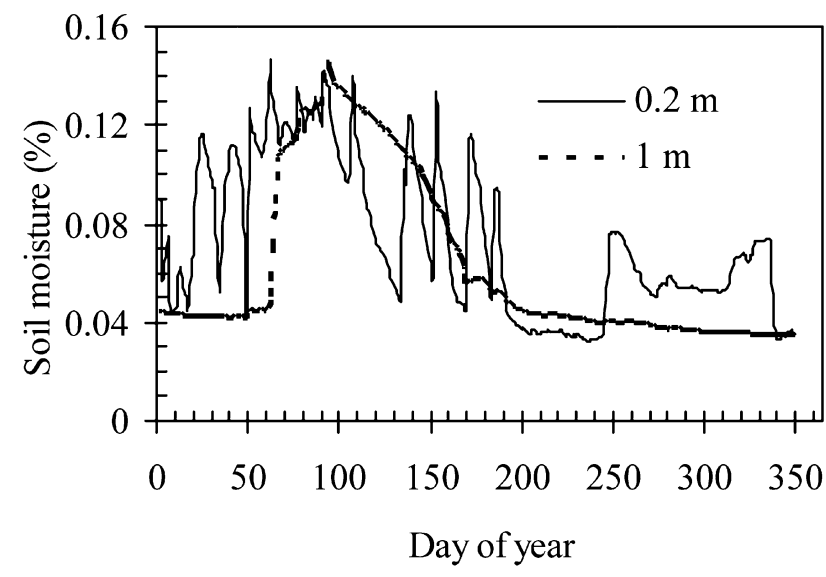

Fig. 2 Seasonal trends in percent soil volumetric water content at 0.2- and 1-m depths on site in the Nebraska Sandhills.

each sampling date. Tree measurements were not taken in January and February because of below-freezing temperatures. Several unshaded south-facing tree needles (currently growing) or grass leaves (uppermost fully expanded leaves) were measured on each individual, and values were averaged on a per-tree/plant basis for statistical analysis. Net photosynthesis $\left(A_{\text {net }}, \mu \mathrm{mol} \mathrm{m} \mathrm{m}^{-2} \mathrm{~s}^{-1}\right)$, stomatal conductance $\left(g_{\mathrm{s}}\right.$, mol $\mathrm{m}^{-2} \mathrm{~s}^{-1}$ ), and water use efficiency (WUE = netphotosynthesis / transpiration, $\mu \mathrm{mol} \mathrm{m} \mathrm{m}^{-2} \mathrm{~s}^{-1} / \mathrm{mmol} \mathrm{m} \mathrm{m}^{-2} \mathrm{~s}^{-1}$ ) were determined using an open-system infrared gas analyzer, mounted with an LED light source (LICOR-6400-02B; LICOR). Maximum daily net photosynthesis measured at light saturation was recorded between 1000 and 1500 hours solar time, depending on the time of the year. Light response curves were created for three plants per species once a month at 0,50 , 100, 250, 500, 750, 1000, 1500, and $2000 \mu \mathrm{mol} \mathrm{m} \mathrm{m}^{-2} \mathrm{~s}^{-1}$ photosynthetically active radiation (PAR). Diurnal trends were followed on clear days once a month on five plants per species between 0600 and 1900 hours solar time.

\section{Water Potential and Carbon Isotope Discrimination}

Seasonal trends in predawn $\left(\psi_{\text {pre }}, \mathrm{MPa}\right)$ and midday $\left(\psi_{\text {mid }}\right.$, $\mathrm{MPa}$ ) water potentials were followed on the same five individuals per species used in gas exchange once or twice a month using a pressure chamber (PMS Instrument, Albany, OR). Carbon isotope discrimination of leaf material was determined with mass spectrometry once a month (Kansas State University Stable Isotope Laboratory). The needle/leaf materials were dried at $65^{\circ} \mathrm{C}$ for $72 \mathrm{~h}$ and ground. The carbon isotope ratio $\left(\delta^{13} \mathrm{C}\right)$ of each sample was determined by relating the ${ }^{13} \mathrm{C} /{ }^{12} \mathrm{C}$ ratio of the sample $\left(R_{\text {sample }}\right)$ to the ${ }^{13} \mathrm{C} /{ }^{12} \mathrm{C}$ ratio of the Vienna Pee Dee Belemnite standard $\left(R_{\text {standard }}\right)$ :

$$
\left.\delta^{13} \mathrm{C}=\left[\left(R_{\text {sample }} / R_{\text {standard }}\right)\right]-1\right] \times 1000
$$

\section{Statistical Analyses}

Data were analyzed using the SAS statistical package (SAS Institute 1998). Repeated-measures analyses, regressions, and orthogonal contrasts were used to compare species responses and to determine the effects of environmental conditions on measured parameters within and between species. Means were separated using the pairwise mean comparisons in SAS.

\section{Results}

\section{Environmental Conditions}

Air temperature was consistent with the 30 -yr average (High Plains Regional Climate Center, University of NebraskaLincoln), reaching a maximum in August $\left(>30^{\circ} \mathrm{C}\right)$ and a minimum in January and February $\left(-20.9^{\circ} \mathrm{C}\right.$; fig. 1). Total precipitation on site was $370 \mathrm{~mm}, 35 \%$ below the long-term average. The largest seasonal precipitation deficit was observed during the summer $(37 \%)$, followed by spring $(23 \%)$, fall $(22 \%)$, and winter (2\%). The climate diagram (fig. 1) indicates that drought on site started in mid-July (day of year

Table 1

Repeated-Measures Analyses of Seasonal Courses in Measured Parameters in Trees and Grasses in the Semiarid Grasslands of Nebraska

\begin{tabular}{|c|c|c|c|c|c|c|c|c|c|c|c|c|}
\hline \multirow[b]{2}{*}{ Source } & \multicolumn{2}{|c|}{$A_{\text {net }}$} & \multicolumn{2}{|c|}{$g_{\mathrm{s}}$} & \multicolumn{2}{|c|}{ WUE } & \multicolumn{2}{|c|}{$\delta^{13} \mathrm{C}$} & \multicolumn{2}{|c|}{$\Psi_{\text {pre }}$} & \multicolumn{2}{|c|}{$\Psi_{\text {mid }}$} \\
\hline & $F$ & $P$ & $F$ & $P$ & $F$ & $P$ & $F$ & $P$ & $F$ & $P$ & $F$ & $P$ \\
\hline \multicolumn{13}{|l|}{ Grasses: $^{a}$} \\
\hline Date & 12.9 & 0.0001 & 19.3 & 0.0001 & 28.0 & 0.0001 & 0.5 & 0.84 & 10.31 & 0.0001 & 2.75 & 0.0316 \\
\hline Species & 7.12 & $\overline{0.0100}$ & 2.86 & $\overline{0.0965}$ & 12.2 & $\overline{0.0009}$ & 0.08 & 0.89 & 0.43 & $\overline{0.5171}$ & 1.96 & $\overline{0.1692}$ \\
\hline Date $\times$ species & 6.85 & 0.0022 & 0.53 & 0.5892 & 5.84 & 0.0050 & 0.01 & 0.91 & 0.76 & 0.5857 & 1.29 & 0.2867 \\
\hline \multicolumn{13}{|l|}{ Trees: ${ }^{\mathrm{b}}$} \\
\hline Date & 24.5 & 0.0001 & 5.56 & 0.0001 & 1.91 & 0.0624 & 1.95 & 0.14 & 29.61 & 0.0001 & 8.37 & 0.0001 \\
\hline Species & 8.28 & $\overline{0.0046}$ & 0.04 & $\overline{0.8331}$ & 1.68 & 0.1973 & 1.58 & 0.09 & 67.94 & $\overline{0.0001}$ & 15.25 & $\overline{0.002}$ \\
\hline Date $\times$ species & 3.61 & $\overline{0.0007}$ & 1.35 & 0.2249 & 1.26 & 0.2712 & 0.67 & 0.41 & 2.78 & $\overline{0.0015}$ & 0.99 & $\overline{0.4707}$ \\
\hline \multicolumn{13}{|c|}{ Trees vs. Grasses (Jun-Aug): } \\
\hline Date & 11.9 & $\underline{0.0001}$ & 26.4 & 0.0001 & 31.5 & $\underline{0.0001}$ & 8.26 & $\underline{0.0001}$ & 21.69 & $\underline{0.0001}$ & 3.08 & $\underline{0.0130}$ \\
\hline Species & 19.4 & $\overline{0.0001}$ & 0.48 & $\overline{0.4915}$ & 3.94 & $\overline{0.0496}$ & 5.56 & $\overline{0.0001}$ & 32.60 & $\overline{0.0001}$ & 57.92 & $\overline{0.0001}$ \\
\hline Date $\times$ species & 5.13 & $\overline{0.0073}$ & 2.13 & 0.1238 & 1.18 & $\overline{0.0300}$ & 0.10 & $\overline{0.5991}$ & 3.89 & $\overline{0.0030}$ & 3.11 & $\overline{0.0121}$ \\
\hline
\end{tabular}

Note. $\quad A_{\text {net }}=$ photosynthesis; $g_{\mathrm{s}}=$ stomatal conductance; WUE $=$ water use efficiency; $\delta^{13} \mathrm{C}=$ carbon isotope discrimination; $\Psi_{\text {pre }}=$ predawn water potential; $\Psi_{\text {mid }}=$ midday water potentials. Underlined values are statistically significant $(P<0.05)$.

a Panicum virgatum and Schizachyrium scoparium.

b Pinus ponderosa and Juniperus virginiana. 
[DOY] 196) and ended at the beginning of October (DOY 280). Volumetric soil moisture content (fig. 2) was highest in spring and fell to a minimum between July (DOY 190) and September (DOY 245). The seasonal soil volumetric water content was highly variable at the $0.2-\mathrm{m}$ depth, reflecting recent precipitation events. In contrast, the water content at the 1-m depth was less responsive to precipitation events, as expected.

\section{Gas Exchange}

Repeated-measures analysis over the study period showed that maximum $A_{\text {net }}$ at light saturation varied significantly between species and dates (table 1). Stomatal conductance varied between dates but not between species, and WUE varied among grasses (Panicum virgatum and Schizachyrium scoparium) and between the grasses and the trees (table 1). Gas exchange measurements during winter were conducted when maximum air temperatures were above $0^{\circ} \mathrm{C}$. Maximum $A_{\text {net }}$ values were low but positive during this period, showing a possible carbon gain (fig. 3). The average winter $A_{\text {net }}$ and WUE for Pinus ponderosa (1.9 and $1.8 \mu \mathrm{mol} \mathrm{m} \mathrm{m}^{-2} \mathrm{~s}^{-1}$, respectively) were lower than those for Juniperus virginiana (3.0 and $2.2 \mu \mathrm{mol} \mathrm{m} \mathrm{m}^{-2} \mathrm{~s}^{-1}$, respectively). Stomatal conductance, however, did not differ between the two tree species (winter average $=0.11 \mathrm{~mol} \mathrm{~m}^{-2} \mathrm{~s}^{-1}$ ) (fig. 3).

Photosynthesis showed an initial increase in April (DOY 111) and peaked in May (DOY 147) for P. ponderosa $(10.2 \mu \mathrm{mol}$ $\left.\mathrm{m}^{-2} \mathrm{~s}^{-1}\right)$ and $J$. virginiana $\left(8.8 \mu \mathrm{mol} \mathrm{m} \mathrm{m}^{-2} \mathrm{~s}^{-1}\right)$ with improved weather conditions (fig. 3). A decline in $A_{\text {net }}$ was observed from May to June (DOY 168), and values remained relatively low before increasing again by $25 \%$ in $P$. ponderosa and $40 \%$ in J. virginiana in September (DOY 257) with improved weather and soil moisture conditions. Then, as air temperature, day length, and PAR decreased, $A_{\text {net }}$ and $g_{\text {s }}$ values decreased to the minimal rates observed in winter.

The grasses were first measured in early June (DOY 168) after their emergence on site. The $A_{\text {net }}$ and WUE were higher in grasses than in trees in June (DOY 168) and July (DOY 204) (fig. 3). Panicum virgatum had higher photosynthetic rates than $S$. scoparium for most of the growing season. The $A_{\text {net }}$ values declined in August (DOY 233) by $75 \%$ in P. virgatum and $44 \%$ in $S$. scoparium because of water stress and high air temperatures. Grasses began to senesce early in the season (late August), presumably because of the lack of soil moisture.

Diurnal trends in $A_{\text {net }}$ during the growing season (MaySeptember) were generally bell shaped (fig. 4). Maximum $A_{\text {net }}$ in trees was generally reached at 0900 hours in July and August and at 1100 hours in May, June, and September. Maximum $A_{\text {net }}$ in grasses was reached at 1100 hours in August and between 1100 and 1300 hours in June and July, depending on the species. Midday depression in $A_{\text {net }}$ was moderate and was observed only in $P$. ponderosa between July and September (fig. 4). Average daily cumulative net photosynthesis was calculated, and results showed that it was highest in $P$. virgatum $\left(0.26 \mathrm{~mol} \mathrm{~m}^{-2} \mathrm{~d}^{-1}\right)$ during the growing season and significantly differed $(P<0.05)$ from that in $S$. scoparium $\left(0.20 \mathrm{~mol} \mathrm{~m}^{-2} \mathrm{~d}^{-1}\right), P$. ponderosa $\left(0.19 \mathrm{~mol} \mathrm{~m}^{-2} \mathrm{~d}^{-1}\right)$, and J. virginiana $\left(0.17 \mathrm{~mol} \mathrm{~m}^{-2} \mathrm{~d}^{-1}\right)$.
Light response curves (data not shown) indicated that $A_{\text {net }}$ increased linearly at low PAR and that $A_{\text {net }}$ saturated at PAR of $400-500 \mu \mathrm{mol} \mathrm{m} \mathrm{m}^{-2} \mathrm{~s}^{-1}$ in trees, while failing to saturate in grasses. There was a positive linear relationship between $A_{\text {net }}$ and $g_{\text {s }}$ and a negative relationship between $A_{\text {net }}$ and vapor pressure deficit for all species (fig. 5).

\section{Water Potential and Carbon Isotope Discrimination}

Repeated-measures analysis over the study period showed that water potential varied between dates, trees (P. ponderosa and $J$. virginiana), and grasses ( $P$. virgatum and $S$. scoparium) but not between the two grass species (table 1). Grasses, on average, had the most negative $\psi_{\text {pre }}$ and $\psi_{\text {mid }}$, followed sequentially by J. virginiana and P. ponderosa (fig. 6). The $\psi_{\text {pre }}$ is an indication of soil and plant water status. It coincided with seasonal volumetric soil moisture content, indicating the onset of moderate soil moisture stress in June, severe stress in July (DOY 200) and August (DOY 233), and recovery in September (figs. 1, 2, 6). The most negative $\psi_{\text {pre }}$ and $\psi_{\text {mid }}$
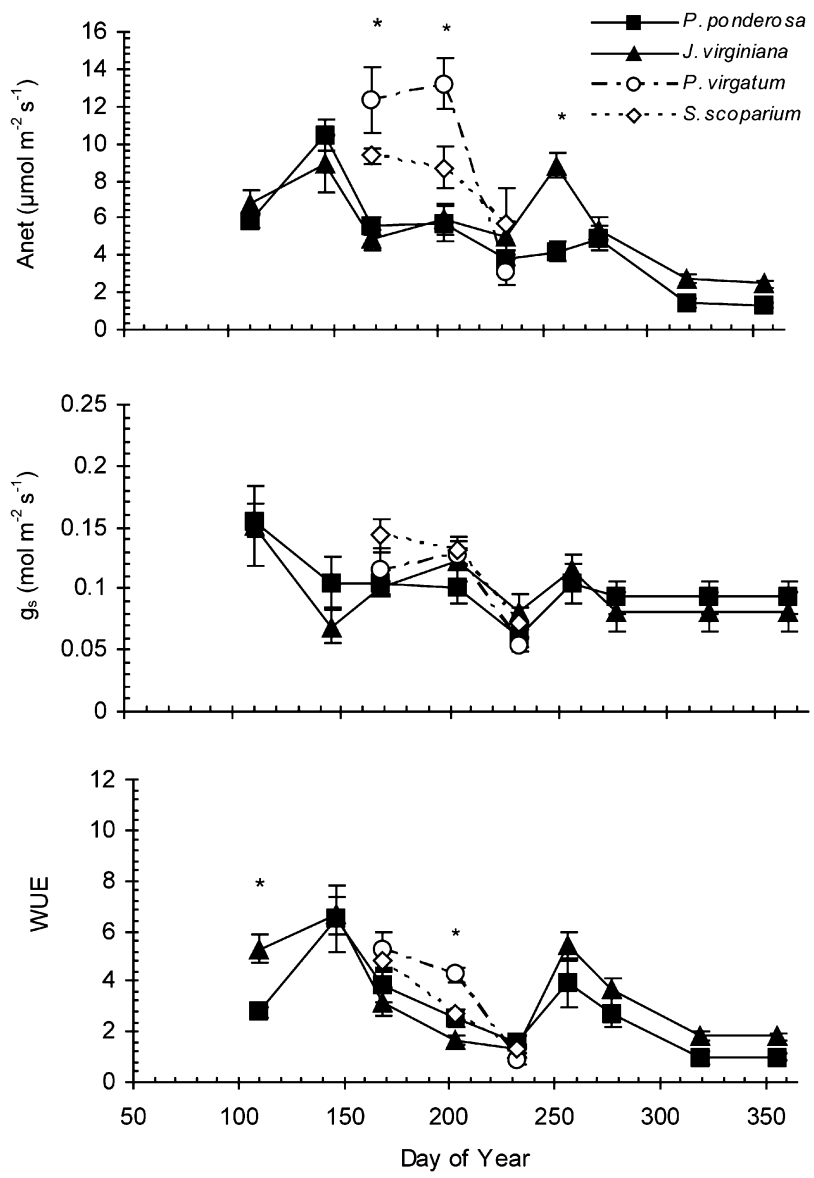

Fig. 3 Seasonal trends of net photosynthesis $\left(A_{\text {net }}, \mu \mathrm{mol} \mathrm{m}^{-2} \mathrm{~s}^{-1}\right)$, stomatal conductance $\left(g_{\mathrm{s}}, \mathrm{mol} \mathrm{m} \mathrm{m}^{-2} \mathrm{~s}^{-1}\right)$, and water use efficiency (WUE; $\mu \mathrm{mol} \mathrm{m} \mathrm{m}^{-2} \mathrm{~s}^{-1} / \mathrm{mmol} \mathrm{m}^{-2} \mathrm{~s}^{-1}$ ) at light saturation, with standard error bars, for trees (Pinus ponderosa and Juniperus virginiana) and grasses (Panicum virgatum and Schizachyrium scoparium) in the Nebraska Sandhills. An asterisk indicates significant differences between species within a date $(P<0.05)$. 

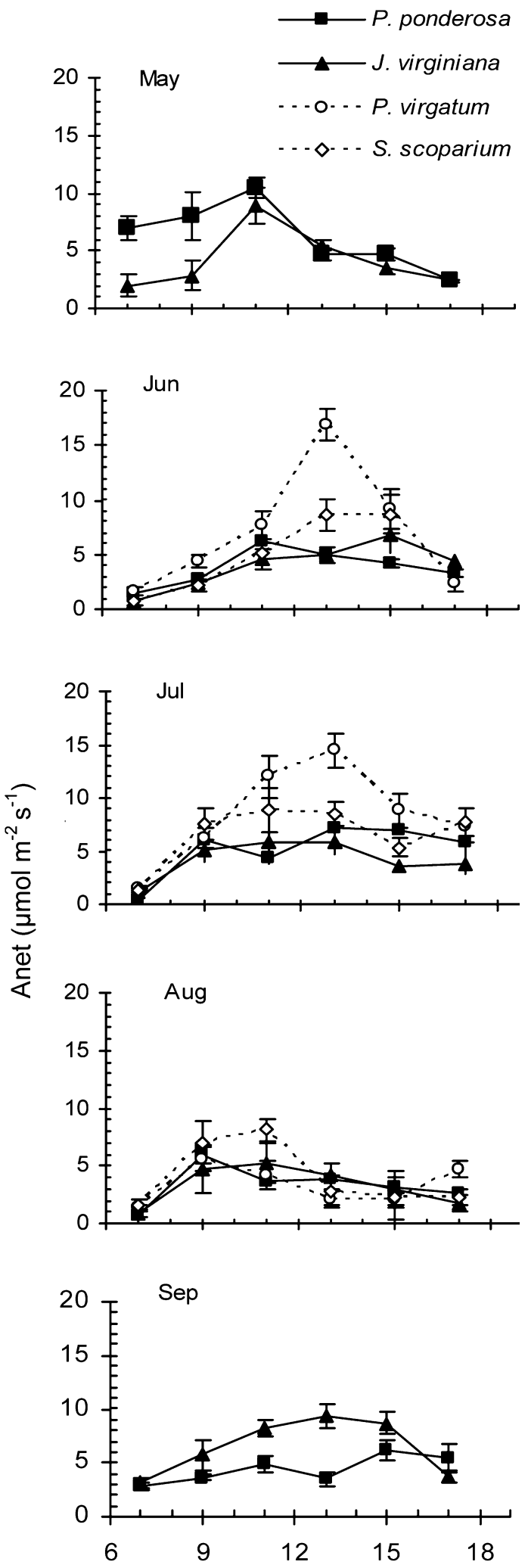

Fig. 4 Diurnal curves of net photosynthesis $\left(A_{\text {net }}, \mu \mathrm{mol} \mathrm{m}^{-2} \mathrm{~s}^{-1}\right)$ with standard error bars, from May to September for trees (Pinus ponderosa and Juniperus virginiana) and grasses (Panicum virgatum and Schizachyrium scoparium) in the Nebraska Sandhills. Maximum occurred in August (DOY 233) for all species. The most negative $\psi_{\text {pre }}(-1.0 \mathrm{MPa})$ and $\psi_{\text {mid }}(-2.5 \mathrm{MPa})$ were observed for the $\mathrm{C}_{4}$ grasses, followed by $J$. virginiana $\left(\psi_{\mathrm{pre}}=-0.95\right.$ and $\left.\psi_{\text {mid }}=-2.0 \mathrm{MPa}\right)$, and $P$. ponderosa $\left(\psi_{\text {pre }}=-0.8\right.$ and $\left.\psi_{\text {mid }}=-1.8 \mathrm{MPa}\right)$. Grasses were unable to recover from the water stress and senesced in late August, whereas trees recovered in September, when soil and environmental conditions began to improve (fig. 6).

Discrimination against carbon isotope differed between trees (P. ponderosa and J. virginiana) and grasses (P. virgatum and $S$. scoparium; table 1), as expected. The $\delta^{13} \mathrm{C}$ averaged $-25.7 \%$ and $-13.5 \%$ in trees and grasses, respectively, and did not exhibit any significant seasonal variation, showing the least plasticity among measured variables (fig. 7).

\section{Discussion}

\section{Gas Exchange}

Stomatal conductance and $A_{\text {net }}$ declined in winter for the trees but remained positive when temperatures were $>0^{\circ} \mathrm{C}$. Photosynthesis in conifers (Troeng and Linder 1982; Teskey et al. 1994; Awada et al. 2003b) and woody invaders (Harrington et al. 1989) is known to occur well beyond the growing season, contributing substantially to carbon gain in other ecosystems. The winter decline in gas exchange is usually attributed to genetically based endogenous rhythms and to declines in temperature and radiation (Richardson 1998). Our results have shown that Pinus ponderosa and Juniperus virginiana, in addition to maintaining positive photosynthetic rates at temperatures above $0^{\circ} \mathrm{C}$, were effectively utilizing water from the deeper unfrozen soil layers on site (investigated using the $\delta^{18} \mathrm{O}$ signatures of precipitation, xylem water, and soil water; Eggemeyer 2005). This indicates a potential carbon gain in these species during winter while grasses are dormant.

Photosynthesis in trees increased with the increase in temperature and radiation in spring, reaching a maximum in May before declining in June with the onset of water stress. Similar seasonal trends have been observed in other studies for J. virginiana (Bahari et al. 1985) and P. ponderosa (Sala et al. 2005). The steeper decline in P. ponderosa is associated with the high stomatal sensitivity in this species to environmental stresses (Law et al. 2001; Martínez-Vilalta et al. 2004). In contrast to $P$. ponderosa, J. virginiana was able to maintain $A_{\text {net }}$ and $g_{\text {s }}$ (fig. 3 ) at more negative water potentials (fig. 6). Pinus ponderosa and J. virginiana were able to avoid and recover from drought stress due, in part, to their ability to access water from deeper in the soil profile (Eggemeyer 2005 ) and in the case of J. virginiana to its additional ability to maintain physiological functions under drought stress (Bahari et al. 1985). Juniperus virginiana is adapted to xeric conditions, with an inherently low stomatal conductance, a high WUE, and an ability to maintain stomatal opening at

air temperature was $29^{\circ}, 34^{\circ}, 30^{\circ}, 39^{\circ}$, and $28^{\circ} \mathrm{C}$; maximum vapor pressure deficit was $3.5,3.1,2.4,3.4$, and $2.1 \mathrm{kPa}$; and maximum PAR was 2002, 1756, 1912, 1701, and $1525 \mu \mathrm{mol} \mathrm{m} \mathrm{m}^{-2} \mathrm{~s}^{-1}$ for the months of May, June, July, August, and September, respectively. 

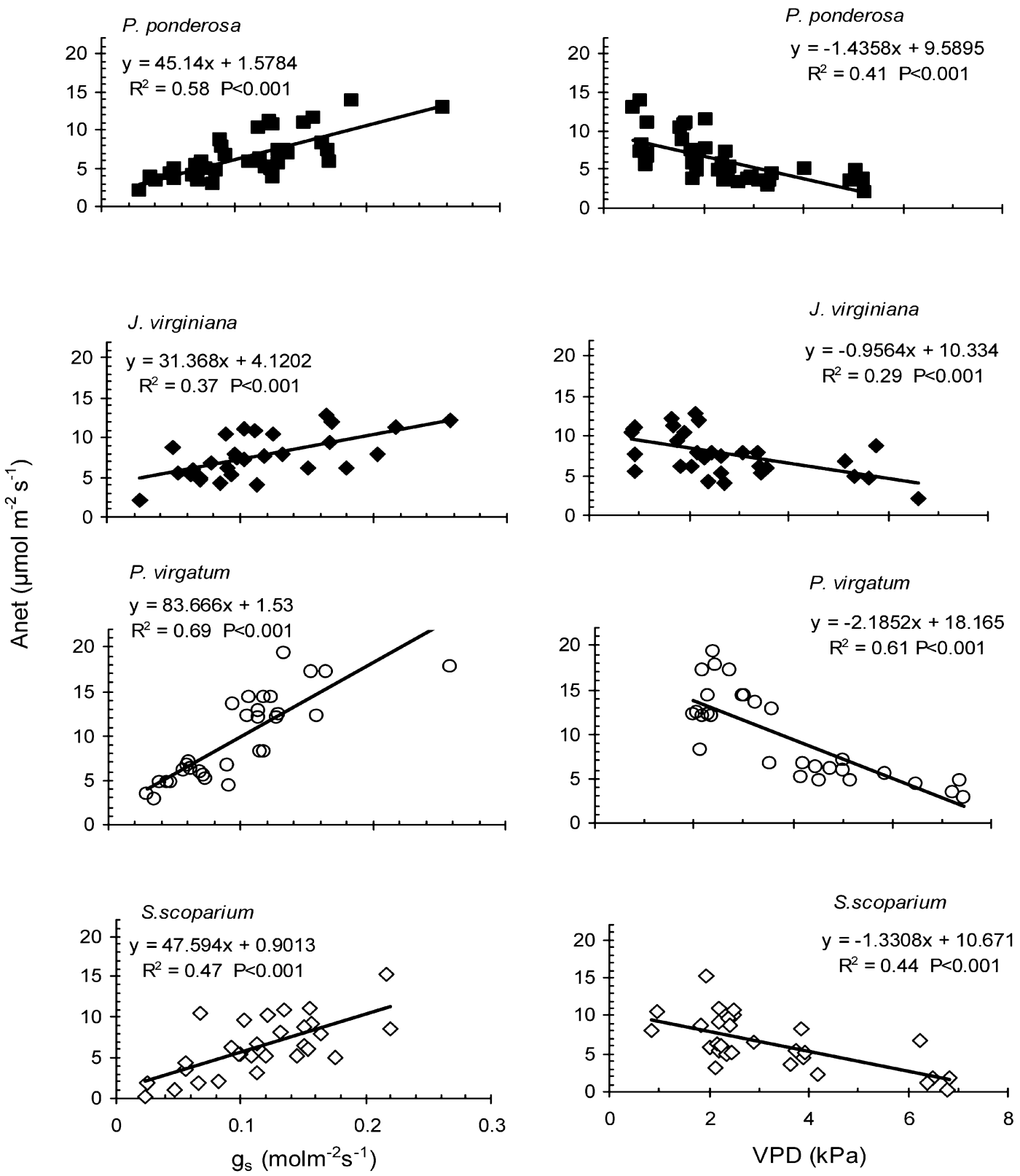

Fig. 5 Net photosynthesis $\left(A_{\text {net }}, \mu \mathrm{mol} \mathrm{m} \mathrm{m}^{-2} \mathrm{~s}^{-1}\right)$ as a function of stomatal conductance $\left(g_{\mathrm{s}}, \mathrm{mol} \mathrm{m}^{-2} \mathrm{~s}^{-1}\right)$ and vapor pressure deficit (VPD, $\left.\mathrm{kPa}\right)$ for trees (Pinus ponderosa and Juniperus virginiana) and grasses (Panicum virgatum and Schizachyrium scoparium) in the Nebraska Sandhills.

low water potentials (Bahari et al. 1985). These results suggest that the two woody species followed different strategies to succeed in the semiarid grasslands of Nebraska. While $P$. ponderosa behaved more like a drought-avoider species, J. virginiana behaved like a drought-tolerant species, which explains its widespread invasion in water-limited grasslands relative to $P$. ponderosa.

The grasses, as expected for $\mathrm{C}_{4}$ species, displayed a significantly higher $A_{\text {net }}$ and WUE in June and July than the trees. The lower photosynthetic rates in the trees $\left(\mathrm{C}_{3}\right)$ relative to the grasses $\left(\mathrm{C}_{4}\right)$ is at least partly due to the limitation on $A_{\text {net }}$ in $\mathrm{C}_{3}$ plants created by greater photorespiration, particularly at high temperatures (Anten et al. 1995; Awada et al. 2003a;
Wedin 2004). The grasses avoided photorespiration by concentrating $\mathrm{CO}_{2}$ at the site of Rubisco in the bundle sheath, allowing them to achieve both higher photosynthetic rates and higher WUE compared to the $\mathrm{C}_{3}$ trees (Ehleringer and Monson 1993). Physiological responses differed among the $\mathrm{C}_{4}$ grasses, with Panicum virgatum having higher maximum $A_{\text {net }}$, higher WUE (fig. 3), and steeper responses of $A_{\text {net }}$ to stomatal conductance and vapor pressure deficit (fig. 5). Panicum virgatum had higher leaf tissue $\mathrm{N}$ concentrations than Schizachyrium scoparium on all three sampling dates in this study (data not shown). Although plant $\mathrm{N}$ use was not a focus in this study and our tissue $\mathrm{N}$ data are poorly replicated, they are consistent with other research on these species 

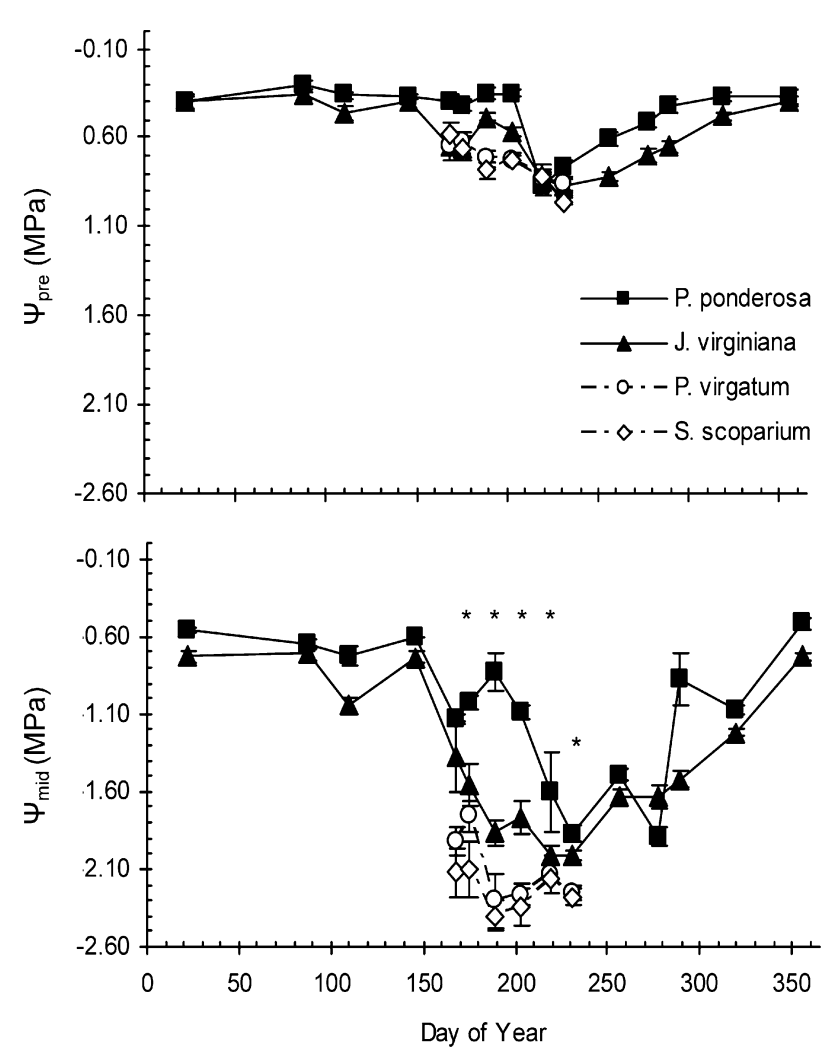

Fig. 6 Seasonal course in predawn $\left(\Psi_{\text {pre }}, \mathrm{MPa}\right)$ and midday $\left(\Psi_{\text {mid }}\right.$, $\mathrm{MPa}$ ) water potentials with standard error bars, for trees (Pinus ponderosa and Juniperus virginiana) and grasses (Panicum virgatum and Schizachyrium scoparium) in the Nebraska Sandhills. An asterisk indicates significant differences between species within a date $(P<0.05)$.

(Craine et al. 2002; Tjoelker et al. 2005). The high photosynthetic rate and WUE of $P$. virgatum were associated with higher leaf tissue $\mathrm{N}$ by Tjoelker et al. (2005). The dependence of photosynthesis on leaf $\mathrm{N}$ is a well-known relationship (Reich et al. 1997). Schizachyrium scoparium, on the other hand, is well documented as having low tissue $\mathrm{N}$ concentrations, which corresponds to high nitrogen use efficiency (NUE) at both the leaf and whole-plant scales (Wedin 2004). Thus, WUE and NUE at the leaf level were inversely correlated for these two grasses (Tjoelker et al. 2005). Physiological differences among $\mathrm{C}_{4}$ grass species are also attributed to stomatal distribution and morphology (Redmann 1985; Salisbury and Ross 1985; Awada et al. 2002) and to photosynthetic subtype (Long 1999). Panicum virgatum and $S$. scoparium differ for these traits as well. These ecophysiological differences among grasses contribute to the spatial distribution of $\mathrm{C}_{4}$ plants in the semiarid grasslands of the Nebraska Sandhills (Schacht et al. 2000; Awada et al. 2002). Summer drought, a usual phenomenon, forced both grasses into dormancy late in the growing season.

\section{Water Potential and Carbon Isotope Discrimination}

The climate diagram, volumetric soil moisture content, $\psi_{\text {pre }}$, and $\psi_{\text {mid }}$ suggested that drought stress occurred during the summer in all species. On average, the grasses experi- enced a $40 \%$ decline in $\psi_{\text {pre }}$ over the growing season, whereas the trees experienced a $25 \%$ decrease. The shallower rooting systems of grasses relative to trees contributed to the observed more negative water potentials. Schizachrium scoparium and P. virgatum have fibrous root system that can extend up to 0.6 and $1.2 \mathrm{~m}$ deep, respectively (Stubbendieck et al. 1985). In comparison, the significantly less negative and relatively stable $\psi_{\text {pre }}$ and $\psi_{\text {mid }}$ during the period of extreme water stress in trees suggest that $P$. ponderosa and, to a lesser extent, J. virginiana were able to maintain less negative water potentials by controlling stomatal opening (Sala et al. 2005) and by accessing deeper water via their extensive rooting systems (Ryan et al. 2000; Maherali and DeLucia 2001; Eggemeyer 2005) that can penetrate 12 and $7.5 \mathrm{~m}$ deep, respectively (Burns and Honkala 1990). Although deep-rooted trees and shrubs have been shown to benefit grasses through hydraulic lift of soil moisture during dry periods, this was unlikely in this study. The grasses we studied were located well away from tree canopies, and the grasses' physiological responses corresponded to the low soil moisture contents observed.

Many studies have shown that carbon isotope composition can be a reliable indicator of water status in plants (Pate and Arthur 1998; Robinson et al. 2000). The $\mathrm{C}_{4}$ grasses discriminate less against carbon isotopes than trees because PEP carboxylase has very little discrimination against carbon isotopes and is not affected by water stress (Farquhar et al. 1989). There were no significant differences between the carbon isotope discrimination values of $P$. ponderosa and J. virginiana or between those of $P$. virgatum and $S$. scoparium. Drought stress typically results in $\delta^{13} \mathrm{C}$ signatures becoming less negative in $\mathrm{C}_{3}$ plants because of the reduction of internal $\mathrm{CO}_{2}$ concentration $\left(\mathrm{C}_{\mathrm{i}}\right)$ in the leaves caused by stomatal closure. In this study, $\delta^{13} \mathrm{C}$ displayed the least plasticity in response to environmental stresses on an intra-annual timescale. Similarly, Aspelmeier and Leuschner (2004), Wallin et al. (2004), and Sala et al. (2005) reported little or no change in carbon isotope discrimination in response to environmental stresses. Sala et al. (2005) attributed the lack of plasticity to the relative overall stability of internal $C_{i}$ to

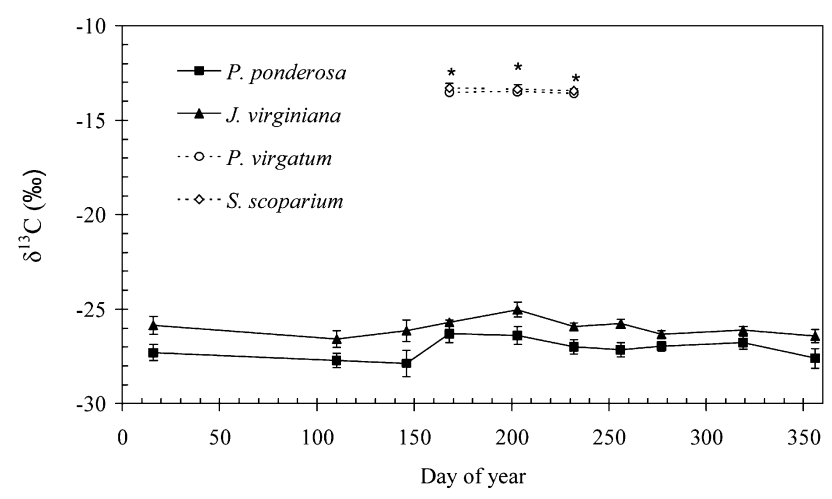

Fig. 7 Seasonal course of $\delta^{13} \mathrm{C}(\%)$ with standard error bars for Pinus ponderosa, Juniper virginiana, Panicum virgatum, and Schizachyrium scoparium in the Nebraska Sandhills. An asterisk indicates significant differences between species $(P<0.05)$. 
external $\mathrm{C}_{\mathrm{a}}$ ratio in some species, adding that under favorable conditions, the increase in $C_{i}$ due to the increase in stomatal conductance may be offset by the increase in photosynthetic rates.

\section{Conclusion}

In the semiarid grasslands in Nebraska, trees coexist with grasses. In recent decades, we have seen a vegetation shift in communities from open grasslands to savannas and sometimes closed-canopy forests. Fire appears to be a critical factor controlling vegetation distribution in several major biomes, including grasslands and savannas (Bond et al. 2005). In fact, climate in these ecosystems does not limit tree establishment (Wells 1965; Richardson 1998), as has been shown by fire suppression (Bond and Van Wilgen 1996) or fire introduction experiments (D'Antonio and Vitousek 1992). Pinus ponderosa and Juniperus virginiana possess avoidance and/or tolerance strategies that allow them to deal physiologically with soil moisture stress in semiarid grassland environments. The deeper roots of $P$. ponderosa and, to a lesser extent, J. virginiana permit these species to access water from below the frozen soil profile during winter (Eggemeyer 2005), to avoid drought stress during the summer, and to facilitate their survival on xeric sites (Smith 1985; Kolb and Robberecht 1996b). This source of water is not available to grasses, forcing them into dormancy earlier in the season during drought years while trees continue to function.

In conclusion, $P$. ponderosa and J. virginiana appear to be well suited for survival in a semiarid grassland like the Nebraska Sandhills, provided that (i) sufficient soil moisture exists in early spring for these $C_{3}$ species, (ii) deep $(>1.5 \mathrm{~m})$ soil moisture persists during drought periods, and (iii) fire suppression continues to be a dominant policy. Both species can continue to invade and displace dominant grasses. This expansion of $\mathrm{C}_{3}$ woody vegetation into the $\mathrm{C}_{4}$ grassdominated Nebraska Sandhills has potentially important implications for local and regional biodiversity and geochemistry. The shift from grass to tree species is likely to change plant productivity, standing-plant biomass, and the relative allocation and storage of carbon in above- and belowground components (Knapp et al. 1998) and may contribute to a decline of ground water recharge and change in regional hydrology (Huxman et al. 2005).

\section{Acknowledgments}

This work was supported by the McIntire-Stennis Forestry Research Funds, USDA, and an Interdisciplinary Research grant from the Agricultural Research Division, University of Nebraska-Lincoln. We thank Kenneth Elgersma for field assistance. K. D. Eggemeyer would like to acknowledge a fellowship from the Center for Great Plain Studies.

\section{Literature Cited}

Anten NPR, F Schieving, MJA Werger 1995 Patterns of light and nitrogen distribution in relation to whole canopy carbon gain in $\mathrm{C}_{3}$ and $\mathrm{C}_{4}$ mono- and dicotyledonous species. Oecologia 101: 504-513.

Archer S 1995 Tree-grass dynamics in a Prosopis-thornscrub savanna parkland: reconstructing the past and predicting the future. Ecoscience 2:83-99.

Aspelmeier S, C Leuschner 2004 Genotypic variation in drought response of silver birch (Betula pendula): leaf water status and carbon gain. Tree Physiol 24:517-528.

Awada T, LE Moser, WH Schacht, PE Reece 2002 Stomatal variability of native warm-season grasses from the Nebraska Sandhills. Can J Plant Sci 82:349-355.

Awada T, MEL Perry, WH Schacht 2003a Photosynthetic and growth response of $\mathrm{C}_{3}$ Bromus inermis and the $\mathrm{C}_{4}$ Andropogon gerardii to tree canopy cover. Can J Plant Sci 83:533-540.

Awada T, K Radoglou, M Fotelli, and HIA Constantinidou 2003b Ecophysiology of seedlings of three Mediterranean pine species in contrasting light regimes. Tree Physiol 23:33-42.

Bahari ZA, WC Parker, SG Pallardy 1985 Photosynthesis, water relations, and drought adaptation in six woody species of oak-hickory forests in central Missouri. For Sci 31:557-569.

Belsky AJ 1994 Influences of trees on savanna productivity: tests of shade, nutrients, and tree-grass competition. Ecology 75:922-932.

Bond WJ, BW Van Wilgen 1996 Fire and plants. Chapman \& Hall, London.

Bond WJ, FI Woodward, GE Midgley 2005 The global distribution of ecosystems in a world without fire. New Phytol 165:525-538.

Bragg TB, LC Hulbert 1976 Woody plant invasion of unburned Kansas bluestem prairie (Andropogon-Panicum-Sorghastrum). J Range Manag 29:19-24.

Briggs JM, GA Hoch, LC Johnson 2002 Assessing the rate, mecha- nisms, and consequences of the conversion of tallgrass prairie to Juniper virginiana forest. Ecosystems 5:578-586.

Brown JR, J Carter 1998 Spatial and temporal patterns of exotic shrub invasion in an Australian tropical grassland. Landsc Ecol 13: 93-103.

Burns RM, BH Honkala 1990 Silvics of North America. Vol 1. Conifers. Agriculture Handbook 654. USDA Forest Service, Washington, DC.

Craine JM, D Tilman, D Wedin, P Reich, M Tjoelker, J Knops 2002 Functional traits, productivity and effects on nitrogen cycling of 33 grassland species. Funct Ecol 16:563-574.

D'Antonio CM, PM Vitousek 1992 Biological invasions by exotic grasses, the grass/fire cycle, and global change. Annu Rev Ecol Syst 23:63-87.

Dussart E, P Lerner, R Peinetti 1998 Long-term dynamics of two populations of Prosopis caldenia Burkart. J Range Manag 51: 685-691.

Ebert J 2005 Fire shapes global vegetation: a world that never burned would contain twice as much forest. Nature News (Jan. 28). doi: 10.1038/news050124-16. http://www.nature.com.

Eggemeyer K 2005 Ecophysiology of trees and grasses in the Nebraska Sandhills. MS thesis. University of Nebraska, Lincoln.

Ehleringer JR, RK Monson 1993 Evolutionary and ecological aspects of photosynthetic pathway variation. Annu Rev Ecol Syst 24: 411-439.

Engle DM, TG Bidwell, ME Moseley 1996 Invasion of Oklahoma rangelands and forests by eastern redcedar and ash juniper. Oklahoma State University Extension Circular E-947. Oklahoma Cooperative Extension Service, Stillwater.

Farquhar GD, JR Ehleringer, KT Hubick 1989 Carbon isotope discrimination and photosynthesis. Annu Rev Plant Physiol Mol Biol 40:503-537. 
Gibson DJ, LC Hulbert 1987 Effects of fire, topography and year-to-year climate variation on species composition in tallgrass prairie. Vegetatio 72:175-186.

Harrington RA, BJ Brown, PB Reich 1989 Ecophysiology of exotic and native shrubs in southern Wisconsin. Oecologia 80:356-367.

Hoch GA 2000 Patterns and mechanisms of eastern redcedar (Juniperus virginiana) expansion into tallgrass prairie in the Flint Hills Kansas. PhD diss. Kansas State University, Manhattan.

Huxman TE, BP Wilcox, DD Breshears, RL Scott, KA Snyder, EE Small, K Hultine, WT Pockman, RB Jackson 2005 Ecohydrological implications of woody plant encroachment. Ecology 86: 308-319.

Jackson RB, JL Banner, EG Jobbágy, WT Pockman, DH Wall 2002 Ecosystem carbon loss with woody plant invasion of grasslands. Nature 418:623-626.

Jones HG 1992 Plants and microclimate. Cambridge University Press, New York.

Knapp AK, JM Briggs, CL Turner 1998 Patterns and controls of aboveground net primary production in tallgrass prairie. Pages 193-221 in AK Knapp, JM Briggs, DC Hartnett, SL Collins, eds. Grassland dynamics: long-term ecological research in tallgrass prairie. Oxford University Press, New York.

Kolb PK, R Robberecht 1996a High temperature and drought stress effects on the survival of Pinus ponderosa seedlings. Tree Physiol 16:665-672.

1996 Pinus ponderosa establishment and the influence of competition with the bunchgrass Agropyron spicatum. Int J Plant Sci 157:509-515.

Law BE, AH Goldstein, PM Anthoni, MH Unsworth, JA Panek, MR Bauer, JM Fracheboud, N Hultman 2001 Carbon dioxide and water vapor exchange by young and old ponderosa pine ecosystems during a dry summer. Tree Physiol 21:299-308.

Le Roux X, T Bariac, A Mariotti 1995 Spatial partitioning of the soil water resource between grass and shrub components in a West African humid savanna. Oecologia 104:147-155.

Long SP 1999 Environmental responses. Pages 215-249 in RF Sage, RK Monson, eds. $\mathrm{C}_{4}$ plant biology. Academic Press, San Diego, CA.

Maherali H, EH DeLucia 2001 Influence of climate-driven shifts in biomass allocation on water transport and storage in ponderosa pine. Oecologia 129:481-491.

Martínez-Vilalta J, A Sala, J Pinol 2004 The hydraulic architecture of Pinaceae: a review. Plant Ecol 171:3-13.

McCarron JK, AK Knapp $2001 \mathrm{C}_{3}$ woody plant expansion in a $\mathrm{C}_{4}$ grassland: are grasses and shrubs functionally distinct? Am J Bot 88 : 1818-1823.

Moleele NM, JS Perkins 1998 Encroaching woody plant species diversity and boreholes: is cattle density the main driving factor in the Olifants Drifts communal grazing lands, south-east Botswana? J Arid Environ 40:245-253.

Pate JS, D Arthur $1998 \delta^{13} \mathrm{C}$ analysis of phloem sap carbon: novel means of evaluating seasonal water stress and interpreting carbon isotope signatures of foliage and trunk wood of Eucalyptus globules. Oecologia 117:301-311.

Redmann RE 1985 Adaptation of grasses to water stress: leaf rolling and stomata distribution. Ann Mo Bot Gard 72:833-842.

Reich PB, MB Walters, DS Ellsworth 1997 From tropics to tundra: global convergence in plant functioning. Proc Natl Acad Sci USA 94:13730-13734.

Richardson DM 1998 Ecology and biography of Pinus. Cambridge University Press, Cambridge.

Robinson D, LLP Hadley, RP Ellis 2000 Using stable isotope natural abundances $\left(\delta^{15} \mathrm{~N}\right.$ and $\left.\delta^{13} \mathrm{C}\right)$ to integrate the stress responses of wild barley (Hordeum spontaneum C. Koch.) genotypes. J Exp Bot 51: 41-50.

Ryan MG, BJ Bond, BE Law, RM Hubbard, D Woodruff, E Cienciala, J Kucera 2000 Transpiration and whole tree conductance in ponderosa pine tress of different heights. Oecologia 124:553-560.

Sala A, GD Peters, LR McIntyre, MG Harrington 2005 Physiological responses of ponderosa pine in western Montana to thinning, prescribed fire and burning season. Tree Physiol 25:339-348.

Salisbury FB, CW Ross 1985 Plant physiology. 4th ed. Wadsworth, Belmont, CA.

SAS Institute 1998 SAS/STAT user's guide. SAS Institute, Cary, NC.

Schacht WH, JD Volesky, D Bauer, AJ Smart, E Mousel 2000 Plant community patterns on upland range in eastern Sandhills. Prairie Nat 32:43-58.

Schenk HJ, RB Jackson 2002 Rooting depths, lateral root spreads and below-ground/above-ground allometries of plants in waterlimited ecosystems. J Ecol 90:480-494.

Scholes RJ, SR Archer 1997 Tree-grass interactions in savannas. Annu Rev Ecol Syst 28:517-544.

Sherfey LE, C Fox, J Nishimura 1965 Soil survey, Thomas County, Nebraska. USDA Soil Conservation Service and Forest Service, Washington, DC.

Shinneman DJ, WL Baker 1997 Nonequilibrium dynamics between catastrophic disturbances and old-growth forests in ponderosa landscapes of the Black Hills. Conserv Biol 11:1276-1288.

Smith WK 1985 Montane forests. Pages 95-126 in BF Chabot, HA Money, eds. Physiological ecology of North American plant communities. Chapman \& Hall, New York.

Steinauer EM, TB Bragg 1987 Ponderosa pine (Pinus ponderosa) invasion in the Nebraska Sandhills prairie. Am Midl Nat 118: 358-365.

Stubbendieck J, JT Nickols, KK Roberts 1985 Nebraska range and pasture grasses. Extension Circular 85-170F. University of Nebraska Cooperative Extension Service, Lincoln.

Teskey RO, HL Gholz, WP Cooper 1994 Influence of climate and fertilization on net photosynthesis of mature slash pine. Tree Physiol $14: 1215-1227$.

Tjoelker MG, JM Craine, D Wedin, PB Reich, D Tilman 2005 Linking leaf and root trait syndromes among 39 grassland and savannah species. New Phytol 167:493-508.

Troeng E, S Linder 1982 Gas exchange in a 20-year-old stand of Scots pine. I. Net photosynthesis of current and one-year-old shoots within and between growing seasons. Physiol Plant 54:7-14.

Wallin KF, TE Kolb, KR Skov, MR Wagner 2004 Seven-year results of thinning and burning restoration treatments on old ponderosa pines at the Gus Pearson Natural Area. Restor Ecol 12: 239-247.

Walter H 1979 Vegetation of earth and ecological systems of the geo-biosphere. Springer, New York.

Weaver JE 1965 Native vegetation of Nebraska. University of Nebraska Press, Lincoln.

Weaver JE, FE Clements 1938 Plant ecology. McGraw-Hill, New York.

Wedin D $2004 \mathrm{C}_{4}$ grasses: resource use, ecology, and global change. Pages 15-50 in LW Moser, BL Burson, LE Sollenberger, eds. Warm-season $\left(\mathrm{C}_{4}\right)$ grasses. American Society of Agronomy, Madison, WI.

Wells PV 1965 Scarp woodlands, transported grassland soils, and concept of grassland climate in the Great Plains region. Science 148: 246-249. 